\title{
Insurgent Women: Female Combatants in Civil Wars. By Jessica Trisko Darden, Alexis Henshaw and Ora Szekely. Washington, DC: Georgetown University Press, 2019.
}

Deborah Sibila, Ph.D.

Texas A\&M University, Corpus Christi, Deborah.Sibila@tamucc.edu

Follow this and additional works at: https://digitalcommons.usf.edu/jss

pp. 162-164

\section{Recommended Citation}

Sibila,, Deborah Ph.D.. "Insurgent Women: Female Combatants in Civil Wars. By Jessica Trisko Darden, Alexis Henshaw and Ora Szekely. Washington, DC: Georgetown University Press, 2019.." Journal of Strategic Security 14, no. 3 (2021) : 162-164.

DOI: https://doi.org/10.5038/1944-0472.14.3.1977

Available at: https://digitalcommons.usf.edu/jss/vol14/iss3/8

This Book Review is brought to you for free and open access by the Open Access Journals at Digital Commons @ University of South Florida. It has been accepted for inclusion in Journal of Strategic Security by an authorized editor of Digital Commons @ University of South Florida. For more information, please contact digitalcommons@usf.edu. 
Insurgent Women: Female Combatants in Civil Wars. By Jessica Trisko Darden, Alexis Henshaw and Ora Szekely. Washington, DC: Georgetown University Press, 2019. 


\section{Insurgent Women: Female Combatants in Civil Wars. By Jessica Trisko Darden, Alexis Henshaw and Ora Szekely. Washington, DC: Georgetown University Press, 2019. ISBN 978-1626166660. 102 Pages. Notes. Sources cited. Paperback (\$16.95) and Kindle e-book (\$9.95)}

Reviewed by

Deborah A. Sibila, Ph.D.

Texas A\&M University, Corpus Christi

In their book, Insurgent Women: Female Combatants in Civil Wars, authors Jessica Trisko Darden, Alexis Henshaw, and Ora Szekely, fill a void in the security studies literature by offering an extensive look into the presence and impact of women in nonstate armed groups. The authors who possess a wealth of expertise on the subject matter, explore the roles of female rebels in three major contemporary global conflicts: the ongoing civil war in Ukraine; the conflicts in the Kurdish regions of Turkey, Syria, and Iraq; and the civil war in Colombia. Darden and her colleagues use an imposing range of sources - including interviews, archival materials, and propaganda - to provide readers with a tremendous amount of information in four short, but comprehensive chapters. Unlike previous authors, rather than trying to explain the existence of female combatants, Darden and colleagues take a different approach and focus on better understanding how these women are recruited, how they participate in armed conflict, and how they contribute to conflict resolution and peacebuilding. More specifically, the book seeks to explain why women fight, how women fight, and how women help bring an end to fighting ( $\mathrm{p}$. 1).

In the initial chapter of the book, Darden and her colleagues focus on the diversity in women's motivations and participation in the nonstate armed groups within the Ukraine conflict. The chapter begins with a historical overview of women's roles in prior regional conflicts and details how women's involvement in the current conflict in Ukraine has evolved. The authors scrutinize the roles that women play in the two main categories of nonstate armed groups (pro-government and separatist) and consider some broad themes in their motives for joining these groups. 
Unsurprisingly, the authors determine that there are considerable variations in women's roles and motivations across Ukraine's armed groups as well as within specific armed groups (p. 26). In the second chapter of the book, the authors provide an overview of the Kurdish national movements in Syria, Turkey, and Iraq, followed by a discussion of the roles that women play within the Kurdish militant groups in each of those countries. The authors offer an analysis of the reasons for the variations of women roles in the various Kurdish armed movements and discuss the consequences of these disparities for the armed Kurdish factions within each country and for overall regional geopolitics. Interestingly, Darden and colleagues posit that Kurdish groups that recruit women fighters end up with a better quality of soldier, or at least with soldiers who are more ideologically committed (p. 50).

The third chapter of this book examines the evolution of the mobilization processes of women fighters in two major Colombian armed groups, Fuerzas Armadas Revolucionarias de Colomba (Revolutionary Armed Forces of Colombia, or FARC) and the Ejército de Liberacion Naciónal (National Liberation Army, or ELN). Darden and her colleagues argue that many women in Colombia do not join militant groups because of ideology or political reasons, rather other factors such as individual security and belonging are the primary motivating factors in their decision to join an armed group (p. 65). The authors close the chapter with an examination of the various roles that Colombia's female combatants played in the country's peace negotiations as well as in post-conflict disarmament, demobilization, and reintegration (DDR).

In the final chapter of the book, Darden and colleagues briefly explore three additional contemporary cases of nonstate armed actors that recruit women: Islamic State in Iraq and Syria (ISIS), Boko Haram, and alShabaab. According to the authors, women in these Salafi-Jihadi groups are mostly confined to noncombat roles, although there are exceptions, with some women serving as suicide bombers, snipers, or torturers. Additionally, Darden and her colleagues furnish readers with six primary findings derived from their research of female combatants. These findings include the acknowledgement that there is no one single profile of a female combatant, that women serve in a broad range of roles within these groups, and that women's motivations for joining nonstate armed groups vary, just as they do among individual men (p. 78). Appropriate policy 
responses to female combatants are explored specifically with regards to mitigating the recruitment of women into armed groups as well as encouraging their participation in DDR programs. The final chapter concludes with recommendations for the direction of further scholarship on the presence and impact of women in nonstate armed groups.

Insurgent Women: Female Combatants in Civil Wars Insurgent is a wellstructured and well-written book. The text has a strong central thesis, which is forcefully argued throughout. A notable weakness of the book is the very narrow scope in the case selection. Geographically, none of the primary cases discussed come from North America, South Asia, East Asia, or Africa. Additionally, all the groups that are examined are ideologically secularist. The authors attempt to address these gaps in the final chapter; however, their assessment of women's involvement in the Salafist organizations of Boko Haram, al-Shabaab, and the Islamic State of Iraq and Syria (ISIS) lacks the depth of analysis found in previous chapters and must be considered cursory at best.

Darden and colleagues' monograph on women's involvement and impact in non-state armed groups is a welcomed addition to the study of women and armed conflict, as more academic research is crucial in understanding the variation and fluidity of women's roles in this area. Insurgent Women: Female Combatants in Civil Wars Insurgent is an important, relevant, and revealing book that will appeal to both scholars and practitioners in the security and policymaking sectors. This text is an excellent addition to criminal justice, security studies, and other courses examining women's participation in insurgent organizations. For policymakers, this book further highlights the critical importance of addressing gender issues when designing counterinsurgency strategies. Additionally, the book's length and authors' straightforward writing style will appeal to general readers who would like to expand their knowledge of gender and conflict. Anyone interested in exploring insurgent women's roles and their motivations in engaging in armed conflict should immediately purchase and read this thought-provoking text. 